\title{
Does Disclosure of Internal Control Deficiencies and its Repair Contribute to the Promotion of Enterprise Value?
}

\author{
$\mathrm{Na} \mathrm{LIU}{ }^{*}$ \\ Guangdong University of Foreign Studies South China Business College, Guangdong \\ ${ }^{*}$ Corresponding author
}

Keywords: Internal control defects, Defect repair, Enterprise value.

\begin{abstract}
The internal control of listed companies may have defects in the process of operation, and Information disclosure is the process of information transformation and transmission among different interest groups, or it can be understood as the process of information reprocessing and value appreciation. So the research on the disclosure of internal control deficiencies and repair can promote the construction of enterprise internal control system and disclosure of high quality internal control information. Thus this paper takes A-share listed companies in Shanghai and Shenzhen stock markets as the research object, which disclose internal control self-assessment report in the 2015-2016 years, using double $T$ test and regression analysis to verify the disclosure of internal control deficiencies and repair will enhance the value of the company or not. The results show that investors are more concerned about the opinions of the third parties rather than the information disclosed by the enterprises, thus affecting the value of the enterprise. And find that the restoration of internal control deficiencies, especially major / important defects repair, which can't enhance the value of the enterprise, and will reduce the value of enterprises in the year. Due to the endogeneity of enterprise internal control and the delay of signal, repair defects in long-term economic impact on the enterprise value is more worthy of attention.
\end{abstract}

\section{Introduction}

In recent years, due to the imperfect risk monitoring mechanism in internal control system, it is not uncommon for enterprises to fail or find financial fraud. In China, the turbulence caused by the securities market is also turbulent, such as the intention of "Shenzhen Maslong" to land on the gem board, but failed to pass the audit due to internal control problems. Financial fraud such as "Yin Guangxia", "Sichuan Chemical Company Affair", "Green-land", "WFB" and "Sichuan Lutianhua Company Affair" have all caused extremely bad influence. In order to restore public confidence in listed companies, China has developed strict management procedures for internal control and information disclosure. The disclosure of internal control defect information is the key link of the internal control information disclosure and the sensitive information of investors and other stakeholders. According to The White Paper on Internal Control of Chinese Listed Companies in 2016, the disclosure ratio of major defects and major defects in listed companies increased year by year from 2011 to 2015.Among them, the proportion of major defect disclosure increased from $0.16 \%$ to $1.54 \%$. The proportion of important defect disclosure increased from $0.76 \%$ to $2.10 \%$. In addition to 2012 and 2015, the proportion of general defect disclosure is between $10 \%$ and $12 \%$.In 2016, the listed company revealed a total of 159 internal control defects and important defects, and $31.45 \%$ of the defects were still not effectively corrected as of the date of the report. Of the remaining $25.79 \%$ of defects that did not distinguish the correction date, $21.38 \%$ of the defects were not corrected effectively ${ }^{[1]}$. Therefore, the disclosure and rectification of internal control defects of listed companies are not optimistic. Disclosure of internal control defects is passed a "bad news" to the market and it will produce certain negative effects, the company is not willing to disclose internal control defect information, but in the long run it will produce certain positive impact, especially after the disclosure of the defect correction (Mirela Dobre, 2011) ${ }^{[2]}$. If the disclosure of internal control defects will inform the capital market in a timely manner and whether it will affect the value of the enterprise? Through the actual test of real data, we can improve the disclosure level 
of internal control information of listed companies, promote the development of the company and protect the interests of investors and other stakeholders.

\section{Literature Review \& Research Hypothesis}

\section{Disclosure of Internal Control Defect \& Enterprise Value}

Disclosure of internal control defects and the enterprise value of the relationship between research, there are three kinds of research results in general. They are negative correlation, positive correlation and having no significant relation.

The disclosure of internal control defect information will send a negative signal to the capital market, and the more serious the internal control defects are, the more stock price will fall. (Hanmersley, 2008) ${ }^{[3]}$. It is visible that the company's internal control of major defect disclosure will have a negative impact on its performance. (Suraj Srinuvasan 2008)From the perspective of corporate financing cost research disclosure of internal control major defects affect the value of the company, the results found that the promulgation of mandatory disclosure policies make corporate financing costs increase, and then make the value of the enterprise low ${ }^{[4]}$. Some foreign scholars who focus on the internal control of IT have concluded that there is a significant negative correlation between the disclosure of internal control defect and its performance.(Ahuja and so on, 2012 \& Kuhn and so on,2013). ${ }^{[5,6]}$ Domestic scholar, Tian Gaoliang (2011), Chi Guohua (2012), Yang Xiulling (2013)obtained the same conclusion through empirical test. ${ }^{[7,8,9]}$ Wang Lihua and so on (2016) took 2012-2014 a-share listed company of Shanghai Stock Market as the research sample and studied The influence of internal control information disclosure on the operating performance of listed companies under compulsory disclosure, then they found that listed companies disclosing internal control defects have poor operating performance after disclosing internal control information. $^{[10]}$

Through the arrangement of related information, some scholars believe that the internal control defect information disclosure and the company's performance are positively correlated.

Ashbaugh-Skaife (2008) found that internal control defect information disclosure can reduce the number of errors in processing financial information, which can improve the performance of the company ${ }^{[11]}$. Similarly, Aigbe Akhigbe and so on (2010) showed that from the perspective of shareholders' wealth effect, the implementation of sarbanes is beneficial to enhance shareholders' wealth effect, and the effect is more obvious in technology companies ${ }^{[12]}$. Domestic scholar, Sheng Changyan (2012) using the data of Chinese a-share listed companies in 2010, verified the relationship between the disclosure of internal control defect information and the company's performance. And it is found that it is beneficial to improve the company's performance when internal control defect information is especially full disclosed ${ }^{[13]}$. However, some scholars believe that the disclosure of internal control defects has no impact on the enterprise value promotion (Beneish, 2008) ${ }^{[14]}$.

Generally speaking, from domestic and international studies on internal control defects and enterprise value correlation, it can be seen that there is no unified research conclusion between the two. From the present situation of Chinese listed company disclosure of internal control defects information, voluntary disclosure of the listed company internal control significant/important defects account for less than 5\% in 2015.There is a common misconception in management layer that disclosure of internal control defects is more stressful than non-disclosure. In particular, the full disclosure of internal control defect information is a "bad news" signal to the market because investors would believe there is a uncertainty risk in the company, leading to a fall in share prices and a decline in the value of the company. According to the signal transmission theory proposed by Stephen Ross in 1974, usually, enterprises which have a good internal control construction and a good operating performance will be voluntary to disclose internal control information, give investors a signal that the internal control system is well established and make the stocks rise and enhance market value. Based on this, the first research hypothesis, $\mathrm{H} 1$, is proposed: 


\section{H1: The disclosure of internal control defects will enhance the value of the company under the control of other influencing factors.}

\section{Internal Control Defect Repair and Enterprise Value}

Foreign scholars on internal control defect repair and enterprise value, Wu, Jia and so on, (2011) their research shows that internal control defect repair has a significant positive effect on enterprise value $^{[15]}$. Song Jingjing (2015) Take the list of 413 non-financial mainboard listed companies that disclosed general defects and major/important defects in 2011-2012 as the object of study. Analyze the influence of listed companies' disclosure and repair of internal control defects on enterprise value and the result show that after the listed company fixes internal control defects, the enterprise value cannot be promoted in the short term ${ }^{[16]}$. Du Jianju (2017), took the list of Shanghai and shenzhen stock listed companies from 2013 to 2015 as the sample of study, which indicates that internal control defect disclosure and its correction to the value of the enterprise. And found that companies disclosing internal control defects are less valuable than those do not disclose internal control defects, and the correction of internal control defects can have a positive impact on the operation and management of enterprises ${ }^{[17]}$. The existence of internal control defects can not guarantee the security of the enterprise's assets, which will cause the enterprise stakeholders to doubt the operation and management of the company, thus affecting the value of the enterprise. Consequently, only continuously repairing internal control defects and improving the internal control system can the enterprise run well and improve the operating efficiency of the enterprise, which improve the value of the enterprise. Based on this, the first research hypothesis, $\mathrm{H} 2$, of this paper is proposed:

H2: Under the condition of controlling other influencing factors, the internal control defect repair will promote the enterprise value.

\section{Study Design}

\section{Variables Defined}

\section{(1) Enterprise Value}

From the perspective of time, there are three kinds of enterprise value, which are past, present and future. The past value refers to the book value of the measurement model using the historical cost method, which can reflect the cost of the enterprise in the past, but can not predict the future operation of the enterprise. The present value, also known as the market value, refers to the exchange price reached between the two parties in the fair transaction of information symmetry. The measure of the value of listed and unlisted companies is inconsistent. The value of the future is the present value of the reasonable return of the enterprise in the foreseeable future. Each value concept has advantages and disadvantages, therefore, scholars need to use different enterprise value measures according to their own research. For example, the economic value added (EVA) in accrual basis is easy to be manipulated by management, and the measurement accuracy is not enough. Market value added (MVA), shareholder returns (TSR) and excess return (ER) are the target index of shareholder's financial maximization, which is not suitable for the core index of value creation management. And corporate free cash flow (FCF), the profitability indicator, etc. Therefore, this paper believes that three values should be integrated to determine the value of the enterprise.

(2) Disclosure of Internal Control Defect

The disclosure of internal control defects should clarify the following three issues. The first one is whether the listed company has internal control defects. The second one is what type of internal control defect is. The last one is about third party internal control audit report opinion. At present, there is no unified internal control defect definition standard, nor the internal control defect classification standard. According to related provisions like Enterprise Internal Control Evaluation Guidance, such problems as whether the listed company has internal control defects can be judged on the base of internal control self assessment report, the annual financial report and the internal control audit reports of the third party which the listed company has disclosed. 


\section{(3) Internal Control Defect Repair}

There are two ways to determine internal control defects. The first one is enterprise external method. Gao Shengxing (2013) believe that it would be regarded as the defects have been repaired if the listed company has no violations in the year after the punishment. ${ }^{[18]}$ The second one is enterprise internal method. Song Jingjin (2015) took the reduction rate of internal control defects disclosed in the internal control report as a measure of internal control defect repair. In other words, (the number of defective controls in this year-the number of defective controls on last year)/the number of defective controls on last year. ${ }^{[16]}$ Liu Yanfang (2016) believes if the listed company does not disclose internal control defects in the next year after the disclosure or through relevant indications, and finds that internal control is not defective, It would be believed that the internal control defect of the listed company can be repaired. Otherwise the internal control defect of the listed company is not fixed. ${ }^{[19]}$ Zhu Caijie(2016)According to the severity of the defect, grade the types of major defects and calculate the total score. The score of the next year minus the score of the previous year is measured, indicating the effect of the internal control of major defect repair. ${ }^{[20]}$ Internal control defects repair can not be determined only by whether it has suffered external punishment or whether the internal control defect of the previous year is disclosed in the next year. Therefore, the degree of internal control defects repair is determined by the percentage of the number of the corrected internal control defects. In other words, the number of the corrected internal control defects/total internal control defects.

(4) Miscellaneous Variables

Based on the previous research, this paper selects the company's size, the company's industry, company's performance, free cash flow, capital structure, and the growth of the company and so on as shown in table 1.

Table 1. Definition of variables

\begin{tabular}{|c|c|c|c|}
\hline $\begin{array}{l}\text { Variable } \\
\text { types }\end{array}$ & The variable name & $\begin{array}{l}\text { Variable } \\
\text { symbol }\end{array}$ & Variable declaration \\
\hline $\begin{array}{c}\text { Interpreted } \\
\text { variable }\end{array}$ & The enterprise value & $\mathrm{CV}$ & $\begin{array}{l}\text { Total capital market value/total capital } \\
\text { replacement cost. }\end{array}$ \\
\hline \multirow{4}{*}{$\begin{array}{l}\text { Explanatory } \\
\text { variables }\end{array}$} & $\begin{array}{l}\text { Internal control defect } \\
\text { disclosure }\end{array}$ & IC & $\begin{array}{l}\text { Disclosure of internal control defects is assigned } \\
\text { to } 1 \text {; } \\
\text { Disclosure of internal control but no defect } \\
\text { assignment of } 2\end{array}$ \\
\hline & $\begin{array}{l}\text { Type of internal control } \\
\text { defect }\end{array}$ & ICDT & $\begin{array}{l}\text { The internal control major defect assignment is } \\
1 \text {; } \\
\text { Key defects in internal control are assigned to } 2 \text {; } \\
\text { The internal control general defect assignment is } \\
3 \text {; }\end{array}$ \\
\hline & $\begin{array}{l}\text { Internal control audit } \\
\text { report }\end{array}$ & ICAR & $\begin{array}{l}\text { The assignment of non-standard opinion audit } \\
\text { report is } 1 \text {; } \\
\text { Otherwise } 0 \text {; }\end{array}$ \\
\hline & $\begin{array}{l}\text { Internal control defect } \\
\text { repair }\end{array}$ & ICDDC & $\begin{array}{lllr}\begin{array}{l}\text { Number of } \\
\text { rectification/total } \\
\text { defects. }\end{array} & \begin{array}{l}\text { internal } \\
\text { number }\end{array} & \text { control } & \text { defect } \\
\text { internal } & \text { control }\end{array}$ \\
\hline \multirow{6}{*}{$\begin{array}{c}\text { Control } \\
\text { variables }\end{array}$} & Company size & SIZE & $\begin{array}{l}\text { The natural log of the total assets of the } \\
\text { company. }\end{array}$ \\
\hline & Company's industry & IND & $\begin{array}{l}\text { Classify according to the industry classification } \\
\text { standards of CSRC }\end{array}$ \\
\hline & Profitability & ROE & Return on net assets = operating profit/net assets \\
\hline & Free cash flow & $\mathrm{FCF}$ & The company has its own cash flow/total shares \\
\hline & Financial leverage & LEV & The company's asset-liability ratio \\
\hline & Growth & GROW & $\begin{array}{l}\text { (Operating income of this year - revenue from } \\
\text { last year)/Revenue from last year }\end{array}$ \\
\hline
\end{tabular}

\section{Specification of Model}

To measure the impact of internal control defect disclosure and its repair on the company's value, the following model is established: 


$$
\begin{aligned}
& \mathrm{CV}=\alpha_{0}+\alpha_{1} \mathrm{IC}+\alpha_{2} \mathrm{ICDT}+\alpha_{3} \mathrm{ICAR}+\alpha_{4} \mathrm{SIZE}+\alpha_{5} \mathrm{IND}+\alpha_{6} \mathrm{ROE}+\alpha_{7} \mathrm{FCF}+\alpha_{8} \mathrm{LEV}+\alpha_{9} \mathrm{GROW}+\varepsilon_{1} \\
& \mathrm{CV}=\beta_{0}+\beta_{1} \mathrm{ICDDC}+\beta_{2} \mathrm{SIZE}+\beta_{3} \mathrm{IND}+\beta_{4} \mathrm{ROE}+\beta_{5} \mathrm{FCF}+\beta_{6} \mathrm{LEV}+\beta_{7} \mathrm{GROW}+\varepsilon_{2}
\end{aligned}
$$

In formula (1)and(2), $\alpha_{0}$ and $\beta_{0}$ are constant term. $\alpha_{1}, \alpha_{2} \ldots \alpha_{9}, \beta_{1}, \beta_{2} \ldots \beta_{7}$ are explanatory variables and control variable coefficient. $\varepsilon_{1}, \quad \varepsilon_{2}$ are random error.

\section{Sample Selection}

The empirical test of the relationship between the disclosure and repair of internal control defects and the value of the company took Shanghai and shenzhen A shares disclosed internal control self-evaluation report listed companies from 2015 to 2016 as the object of study. The sample selection is following: (1) Remove small and medium-sized board companies, gem companies and financial companies. Because these types of companies have particularity in accounting measurement and enterprise disclosure requirements of internal control information. (2) Remove listed companies which delisted from 2015 to 2016 (3) Remove the newly listed companies from 2015 to 2016. Because compared with the first year of the company, the internal control report of the following year has more information content. (4) Remove companies which do not disclose internal control reports. (5) Remove listed companies which cannot obtain data on relevant variables. A total of 2,500 sample enterprises were selected. The data of this paper are all from Shenzhen GTA Education Tech Ltd. and manually collected through Sina financial and economics network.

\section{Empirical Test and Result Analysis}

\section{Descriptive Statistics}

According to the study sample selection principle, descriptive statistical analysis was conducted on each variable in the two models, and the results were shown in table 2.A total of 2, 500 data were collected from the model 1 research sample, of which 1,393 companies were disclosed defects, and 1,107 of them were not disclosed. Overall average enterprise value is 3.41, which revealed defects mean enterprise value 2.99, failure to disclose defects mean enterprise value 3.94 , It is preliminary visible whether mean enterprise value of companies disclosed internal control defects is in the larger difference. For model 2, the sample is the full sample of the internal control report which disclosed defects in model 1. That is 1,393 listed companies. Because some of the companies did not disclose the defect fixes in their internal control reports, remove this kind of companies. The last remaining total of 265 companies, of which 144 companies disclosed defective repair, 121 companies did not disclose the defect repair. The mean enterprise value of the total sample was 3.31.Among of it, the mean enterprise value of the samples which disclosed repair defect was 2.93, and the mean enterprise value of the samples which never disclosed repair defect was 3.77 which preliminary reveals that there is a certain difference in the enterprise value of disclosing internal control defects repair. According to the mean of internal control defect disclosure type, 3.04, Chinese listed companies are more willing to disclose the general types of defects, and the impact of the high degree of defect disclosure is not much.

\begin{tabular}{|c|c|c|c|c|c|c|c|c|c|c|c|c|}
\hline \multirow{3}{*}{ Variable } & \multicolumn{6}{|c|}{ Model 1} & \multicolumn{6}{|c|}{ Model 2} \\
\hline & \multicolumn{2}{|c|}{$\begin{array}{c}\text { All the } \\
\text { sample group }\end{array}$} & \multicolumn{2}{|c|}{$\begin{array}{c}\text { Disclosure } \\
\text { defect section }\end{array}$} & \multicolumn{2}{|c|}{$\begin{array}{l}\text { Undisclosed } \\
\text { defect group }\end{array}$} & \multicolumn{2}{|c|}{$\begin{array}{l}\text { All the sample } \\
\text { group }\end{array}$} & \multicolumn{2}{|c|}{ Repair defects } & \multicolumn{2}{|c|}{$\begin{array}{l}\text { Unfixed defect } \\
\text { group }\end{array}$} \\
\hline & Mean & $\begin{array}{c}\text { Varia } \\
\text { nce }\end{array}$ & Mean & $\begin{array}{c}\text { Varia } \\
\text { nce }\end{array}$ & Mean & $\begin{array}{c}\text { Varia } \\
\text { nce }\end{array}$ & Mean & $\begin{array}{c}\text { Varia } \\
\text { nce }\end{array}$ & Mean & $\begin{array}{c}\text { Varia } \\
\text { nce }\end{array}$ & Mean & $\begin{array}{c}\text { Varia } \\
\text { nce }\end{array}$ \\
\hline $\mathrm{N}$ & 2500 & - & 1393 & - & 1107 & - & 265 & - & 144 & - & 121 & - \\
\hline $\mathrm{CV}$ & 3.41 & 6.44 & 2.99 & 3.82 & 3.94 & 8.5 & 3.31 & 5.05 & 2.93 & 4.91 & 3.77 & 5.20 \\
\hline IC & 1.44 & 0.50 & 1 & 0 & 2 & 0 & - & - & - & - & - & - \\
\hline ICAR & 0.06 & 0.24 & 0.09 & 0.28 & 0.03 & 0.17 & - & - & - & - & - & - \\
\hline
\end{tabular}

Table 2. Descriptive statistical analysis of variables 


\begin{tabular}{c|c|c|c|c|c|c|c|c|c|c|c|c}
\hline ICDT & 1.70 & 1.76 & 3.04 & 1.20 & - & - & - & - & - & - & - & - \\
\hline ICDDC & - & - & - & - & - & - & 0.44 & 0.47 & 0.82 & 0.31 & 0 & 0 \\
\hline SIZE & 22.71 & 1.47 & 22.83 & 1.49 & 22.57 & 1.43 & 22.75 & 1.45 & 22.82 & 1.37 & 22.67 & 1.55 \\
\hline IND & 40.97 & 19.72 & 40.57 & 18.78 & 41.47 & 20.84 & 38.80 & 18.22 & 39.69 & 19.79 & 37.73 & 16.18 \\
\hline ROE & 0.03 & 1.32 & 0.04 & 1.11 & 0.01 & 1.54 & 0.07 & 2.14 & 0.19 & 2.83 & -0.08 & 0.71 \\
\hline FCF & -0.09 & 1.68 & 0.02 & 1.62 & -0.23 & 1.73 & -0.09 & 1.36 & -0.15 & 1.42 & -0.01 & 1.29 \\
\hline LEV & 0.50 & 0.22 & 0.51 & 0.22 & 0.49 & 0.22 & 0.54 & 0.22 & 0.54 & 0.22 & 0.55 & 0.22 \\
\hline GROW & 0.55 & 6.49 & 0.47 & 7.45 & 0.64 & 5.03 & 0.19 & 1.20 & 0.30 & 1.57 & 0.07 & 0.45 \\
\hline
\end{tabular}

It can be seen from the value of table 2 variance that due to the different industries of listed companies in China, there are certain differences between the growth ability and enterprise value of the company.

\section{Independent 2-Sample T-Test}

According to whether the enterprise internal control defects in table 2 disclosed the value and influence of the company or not, and the influence of enterprise value after defect disclosure and repair, now make Independent 2-Sample T-Test between these two groups. The result is shown in table 3 .

Table 3. Independent sample $\mathrm{T}$ test

\begin{tabular}{|c|c|c|c|c|c|}
\hline \multicolumn{2}{|c|}{ Project } & $\mathrm{F}$ & Sig. & $\mathrm{t}$ & Sig. (2-tailed) \\
\hline \multirow{2}{*}{$\begin{array}{l}\text { Whether the } \\
\text { defects are } \\
\text { disclosed in } \\
\text { two groups. }\end{array}$} & $\begin{array}{c}\text { Variance is } \\
\text { equal }\end{array}$ & 3.278 & .071 & 1.354 & .177 \\
\hline & $\begin{array}{c}\text { The variance } \\
\text { is different }\end{array}$ & & & 1.347 & .179 \\
\hline \multirow{2}{*}{$\begin{array}{l}\text { Whether the } \\
\text { defect fixes } \\
\text { two groups. }\end{array}$} & $\begin{array}{c}\text { Variance is } \\
\text { equal }\end{array}$ & 26.242 & .000 & -3.692 & .000 \\
\hline & $\begin{array}{c}\text { The variance } \\
\text { is different }\end{array}$ & & & -3.418 & .001 \\
\hline
\end{tabular}

From table 3, it can be preliminarily concluded that there is no significant difference between the two kinds of the mean enterprise value of disclosing internal control defects. However, there is a significant difference between the two types of the mean enterprise value of repairing internal control defects. In order to further examine the impact of internal control defect disclosure and internal control defect repair on enterprise value, the following regression analysis is carried out.

\section{Regression Analysis}

First of all, this paper uses panel data of Shanghai and shenzhen a-share listed companies from 2015 to 2016 to conduct regression analysis of model 1, and the result is shown in table 4.After that, the sample group was divided into two groups: the disclosed defect group and the undisclosed defect group, and the differences between them were analyzed in depth. It can be seen from the results of full sample regression analysis in table 4 that the regression coefficient of the disclosure of internal control defects is 0.46 , that is, the disclosure of internal control defects is positively related to the enterprise value. However, the $\mathrm{T}$ value is 1.03 , indicating that the relationship between the two is not significant. Regression coefficient of internal control audit report is 1.35 and the $\mathrm{T}$ value is 2.87 which shows that there is significant positive correlation between enterprise value and the internal control audit report at the 0.01 level, and then verify the hypothesis 1 .There is a negative correlation between the type of internal control defect and the enterprise value, but the relationship is not significant. It can be seen that investors are more concerned with the opinions of third parties rather than the information disclosed by the enterprises themselves.

Table 4. Regression results of model 1

\begin{tabular}{c|c|c|c|c|c|c}
\hline \multirow{3}{*}{ Variable } & \multicolumn{5}{|c}{ Model 1 } \\
\cline { 2 - 7 } & \multicolumn{2}{|c|}{ All the sample group } & \multicolumn{2}{c}{ Disclose defect section } & \multicolumn{2}{c}{ Undisclosed defect section } \\
\cline { 2 - 7 } & Coefficient & T Value & Coefficient & T Value & Coefficient & T Value \\
\hline Constant & $52.30^{* * *}$ & 26.07 & $36.08^{* * *}$ & 26.60 & $76.79^{* * *}$ & 20.95 \\
\hline
\end{tabular}




\begin{tabular}{|c|c|c|c|c|c|c|}
\hline IC & 0.46 & 1.03 & - & - & - & - \\
\hline ICDT & -0.02 & -0.17 & -0.02 & -0.29 & - & - \\
\hline ICAR & $1.35^{* * *}$ & 2.87 & $0.69^{* * *}$ & 2.28 & $5.12^{* * *}$ & 3.97 \\
\hline SIZE & $-2.29^{* * *}$ & -27.49 & $-1.49^{* * *}$ & -24.16 & $-3.42^{* * *}$ & -20.19 \\
\hline IND & $0.01^{* *}$ & 2.09 & $0.01^{* *}$ & 2.40 & 0.01 & 0.49 \\
\hline ROE & 0.11 & 1.27 & $0.15^{* * *}$ & 2.01 & 0.11 & 0.76 \\
\hline FCF & 0.02 & 0.33 & 0.04 & 0.754 & -0.11 & -0.87 \\
\hline LEV & $3.65^{* * *}$ & 6.60 & $1.00^{* *}$ & 2.40 & $7.91^{* * *}$ & 7.04 \\
\hline GROW & 0.01 & 0.28 & 0.01 & 0.63 & -0.03 & -0.69 \\
\hline $\mathrm{N}$ & \multicolumn{2}{|c|}{2500} & \multicolumn{2}{|c|}{1393} & \multicolumn{2}{|c|}{1107} \\
\hline $\mathrm{R}^{2}$ & \multicolumn{2}{|c|}{0.25} & \multicolumn{2}{|c|}{0.32} & \multicolumn{2}{|c|}{0.29} \\
\hline $\mathrm{F}$ & \multicolumn{2}{|c|}{92.64} & \multicolumn{2}{|c|}{82.94} & \multicolumn{2}{|c|}{64.13} \\
\hline
\end{tabular}

Note: ***The significance level is 0.01 ; **the significance level is 0.05 ; *the significance level is 0.1 .

By table 4 revealed defects and undisclosed defect inspection you can see, the data of the two groups no matter any one of internal control audit opinion and the enterprise value has significant positive correlation, which further illustrate intermediaries in play a role in the disclosure of internal control defects. In terms of control variables, the size of the company is negatively correlated with the enterprise value at 0.01 level, indicating that the larger the company is, the less valuable the enterprise will be. The asset-liability ratio is positively correlated with the enterprise value at the level of 0.05 , indicating that the financial leverage effect of the enterprise has been played. However, the characteristics of the industry and the profitability of the company have a more significant impact on the value of the company. This shows that although enterprises disclose internal control defects, investors still pay close attention to the industry and their profitability. In addition, R 2 of the internal control defect group was disclosed to be 0.32 , which was significantly higher than that of 0.25 of the whole sample group. In addition, all of sample groups, the disclosure defect sample group and the unrevealed defect sample group were all below 10, indicating that there was no serious multicolor in the model.

The internal control report was excluded from the internal control report according to the disclosure of the internal control report in model 1, and a sample of internal control defects was mentioned in the report. A total of 265 listed companies were screened for the test of hypothesis 2 , and the regression results were shown in table 5.

Table 5. Regression results of model 2

\begin{tabular}{|c|c|c|c|c|c|c|}
\hline \multirow{3}{*}{ Variable } & \multicolumn{6}{|c|}{ Model 2} \\
\hline & \multicolumn{2}{|c|}{ All the sample group } & \multicolumn{2}{|c|}{ Disclose defect section } & \multicolumn{2}{|c|}{ Undisclosed defect section } \\
\hline & Coefficient & $\mathrm{T}$ Value & Coefficient & T Value & Coefficient & T Value \\
\hline Constant & $50.78^{* * *}$ & 12.21 & $48.00^{* * *}$ & 6.96 & $54.97^{* * *}$ & 9.71 \\
\hline ICDDC & -0.79 & -1.41 & -1.06 & -0.85 & - & - \\
\hline SIZE & $-2.15^{* * *}$ & -11.14 & $-2.00^{* * *}$ & -6.54 & $-2.36^{\text {**** }}$ & -8.87 \\
\hline IND & 0.02 & 1.23 & 0.01 & 0.76 & 0.02 & 0.93 \\
\hline ROE & -0.07 & -0.58 & -0.07 & -0.55 & 0.16 & 0.29 \\
\hline $\mathrm{FCF}$ & -0.21 & -1.08 & -0.29 & -1.07 & -0.08 & -0.26 \\
\hline LEV & 2.16 & 1.74 & 1.70 & 0.90 & 2.60 & 1.39 \\
\hline GROW & -0.05 & -0.24 & -0.08 & -0.33 & 0.22 & 0.26 \\
\hline $\mathrm{N}$ & \multicolumn{2}{|c|}{265} & \multicolumn{2}{|c|}{144} & \multicolumn{2}{|c|}{121} \\
\hline $\mathrm{R}^{2}$ & \multicolumn{2}{|c|}{0.34} & \multicolumn{2}{|c|}{0.25} & \multicolumn{2}{|c|}{0.43} \\
\hline $\mathrm{F}$ & \multicolumn{2}{|c|}{18.85} & \multicolumn{2}{|c|}{6.58} & \multicolumn{2}{|c|}{14.3} \\
\hline
\end{tabular}

Note: ***The significance level is 0.01 ; **the significance level is 0.05 ; *the significance level is 0.1

Table 5 regression analysis shows that the listed company internal control defect fix is negatively related to the enterprise value into now, the relationship between the regression coefficient of the 
sample group - 0.79 , repair defect sample group of regression coefficient is 1.06 . This shows that the listed company internal control defects after the rectification, the enterprise value will not get promoted and even declined. But the $\mathrm{T}$ value is divided into 1.41 and, shows that defect repair of the internal control of listed companies. There is no significant impact on enterprise value, unable to verify the hypothesis 2 . To analyze the reason, first may be because of too much in the disclosure of the defects in the internal control report of listed company is the general type. For little impact on corporate value, even if repaired the defects of internal control of listed companies. But the underlying problem may not really have to solve; second, some stakeholders like the management of listed companies may only focus on the internal control defects when the listed company was punished, and there is no long-term continuous attention. Therefore, the value of the enterprise cannot be improved in the short term. In the control variables, the size of the company is negatively correlated with the significant level of enterprise value at 0.01 , which indicates that the larger the company is, the less valuable the enterprise will be.

\section{Modify the Model for Further Testing}

According to the regression analysis results of model 2, listed companies internal control defects rectification. There is no significant impact on enterprise value, and the possible reason is that too much in the disclosure of the defects in the internal control report of listed company wihch is the general type, with little impact on the enterprise value leading to the cause. Therefore, the model 2 is modified to introduce the type explanatory variable of internal control defect disclosure and analyze whether the repair degree of different internal control defect types has any influence on the value of the enterprise. The modified model is as follows:

$$
\mathrm{CV}=\beta_{0}+\beta_{1} \mathrm{ICDT}+\beta_{2} \mathrm{ICDDC}+\beta_{3} \mathrm{SIZE}+\beta_{4} \mathrm{IND}+\beta_{5} \mathrm{ROE}+\beta_{6} \mathrm{FCF}+\beta_{7} \mathrm{LEV}+\beta_{8} \mathrm{GROW}+\varepsilon_{2}
$$

A total of 265 listed companies were screened out by model 2, and the regression results were shown in table 6.

Table 6. Regression results of model 3

\begin{tabular}{|c|c|c|c|c|c|c|}
\hline \multirow{3}{*}{ Variable } & \multicolumn{6}{|c|}{ Model 3} \\
\hline & \multicolumn{2}{|c|}{ All the sample group } & \multicolumn{2}{|c|}{ Disclose defect section } & \multicolumn{2}{|c|}{ Undisclosed defect section } \\
\hline & Coefficient & T Value & Coefficient & T Value & Coefficient & T Value \\
\hline Constant & $50.61^{* * *}$ & 12.17 & $49.72^{* * *}$ & 11.67 & $53.699^{* * *}$ & 8.29 \\
\hline ICDT & 0.28 & 1.13 & 0.19 & 1.09 & - & - \\
\hline ICDDC & -0.78 & -1.39 & $-2.17^{* * * *}$ & -3.30 & -0.12 & -0.15 \\
\hline SIZE & $-2.18^{* * *}$ & -11.20 & $-2.13^{* * *}$ & -10.41 & $-2.30^{* * *}$ & -7.65 \\
\hline IND & 0.02 & 1.08 & $0.04^{* *}$ & 2.41 & 0.003 & 0.13 \\
\hline ROE & -0.06 & -0.47 & -0.05 & -0.61 & 0.83 & 1.15 \\
\hline $\mathrm{FCF}$ & -0.22 & -1.19 & -0.18 & -0.96 & -0.35 & -1.20 \\
\hline LEV & 2.20 & 1.7 & 1.36 & 0.87 & $3.71^{*}$ & 1.92 \\
\hline GROW & -0.02 & -0.07 & -0.04 & -0.25 & -0.04 & -0.07 \\
\hline $\mathrm{N}$ & \multicolumn{2}{|c|}{265} & \multicolumn{2}{|c|}{94} & \multicolumn{2}{|c|}{171} \\
\hline $\mathrm{R}^{2}$ & \multicolumn{2}{|c|}{0.34} & \multicolumn{2}{|c|}{0.61} & \multicolumn{2}{|c|}{0.28} \\
\hline $\mathrm{F}$ & \multicolumn{2}{|c|}{16.67} & \multicolumn{2}{|c|}{16.85} & \multicolumn{2}{|c|}{8.94} \\
\hline
\end{tabular}

Note: ***The significance level is 0.01 ;**the significance level is 0.05 ; *the significance level is 0.1

The results from table 6 show that the fitting degree of the modified model is 0.34 and the fitting degree of model 2, indicating the robustness of model 2. The regression results are almost identical. However, the fitting degree was 0.61 , which was significantly higher than 0.34 in the whole sample group. The regression coefficient of major/important defects in the internal control of listed companies was -2.17, and there was a significant negative correlation between 0.01 level and enterprise value. This shows significant/important defects of enterprise internal control of listed companies is larger. The influence of the rectification also needs a certain amount of time, and each a public company on major important defects/division standard is not consistent, including strategy, 
security, environmental protection, production, and many other factors. Therefore, when the major/important defects are corrected, the enterprise value of that year will not be promoted, but will decline.

\section{Conclusion}

In this paper, the actual data of Shanghai and shenzhen a-shares in 2015-2016 are used to verify the internal control defect disclosure and its repair can improve the value of the enterprise. The following conclusions are drawn:

First: Internal control audit opinions and there are significant positive correlation between enterprise value, and the company whether to disclose internal control defects and the internal control defects types which is neither present significant correlation with enterprise value. As a result, investors pay more attention to the opinions of third parties rather than the information disclosed by the enterprises themselves. At the same time, it also indicates that the supervision role of the internal control defect disclosure of the intermediary accounting affairs is recognized. For the listed company itself, it is necessary to perfect the disclosure of internal control defect information and increase the reliability and transparency of the defect information.

Second: The repair of major/major defects in internal control is significantly and negatively correlated with the enterprise value at 0.01 level, while the negative correlation between the repair of internal control general defects and the enterprise value is not significant. This indicates that the repair of internal control defects, especially major/important defects, will not be promoted, but will be declined. Due to the internal nature of internal control and the delay of signal, the long-term economic impact of defect repair on enterprise value deserves more attention.

\section{Acknowledgements}

Youth innovation talent project of Guangdong education department: Study on the economic consequences of internal control defect information disclosure based on wavelet analysis (2015WQNCX201).

\section{Reference}

[1] Shenzhen dibo enterprise risk management technology co. LTD, China's listed companies in 2016 internal control white paper, 2016.

[2] Mirela Dobre, Stock investors' response to disclosures of material weaknesses in internal control[J], Accounting and Management Information Systems,2011,10(3): 397-423.

[3] Hanmersley J S ,Myers L A, Shakespear C. Market Reactions to the Disclosure of Internal Control Weakness and Characteristics of those Weaknesses under Section 302 of the Sarbanes Oxley Aet of 2002[J],Review of Accounting Study, 2008,13(1): 141-165

[4] Joseph D. Piotroski, Suraj Srinuvasan, Regulation and Bonding: The Sarbanes-Oxley Act and the Flow of International Listings [J], Journal of Accounting Research, 2008, 46(2): 83-425

[5] Ahuja M, Kuhn R, Mueller J M, IT Control Weakness and Company Financial Health [J], Available at SSRN1304125. 2012

[6] Kuhn Jr J R, Ahuja M, Mueller J. An examination of the relationship of Internal control weakness to company financial performance and health $[\mathrm{J}]$. International Journal of Accounting and Information Management, 2013, 21(3): 227-240

[7] Tian Gaoliang, Qi Baolei, Cheng Yao, The influence of internal control defects on the relevance of accounting information value - empirical research on Chinese stock market [J], Journal of Xi 'an Jiaotong University (Social Science Edition), 2011.4. 
[8] Chi Guohua, Zhang Chuancai, Han Hongling, The influence of internal control defect information disclosure on the risk perception of individual investors: an experimental study [J], The Audit Research, 2012(2): 105-112

[9] Yang Xiuling, Research on the internal control defects and the company's cable relationship -empirical data from listed companies in China [J], Accounting Communications, 2013(2): 42-45.

[10] Wang Dishu, Li Xue, Research on the influence of internal control information disclosure on the company's operating performance -- based on the empirical data of shanghai-listed a-share listed companies [J], Journal of Nanjing Audit University, 2016.3:18-28.

[11] Ashbaugh-Skaife, H.,D. Collins, W.Kinney, and R.LaFond. The Effect of SOX Internal control Deficiencies and Their Remediation on Accrual Quality [J]. The Accounting Review, 2008, 83(1): 217-250.

[12] Aigbe Akhigbe, Anna D. Martin, Melinda L. Newman, Information Asymmetry Determinants of SarbanesOxley Wealth Effects[J], Financial Management, 2010, 39(3): 1253-1272.

[13] Cheng Changyan, The relationship between the internal control defect information disclosure and the company's performance is from the data of listed companies in China [J], journal of modern finance and economics, Tianjin University of Finance And Economics, 2012.6:88-95

[14] Beneish, M.D.,M.B. Billings, and L.D. Hodder. Internal control weakness and Information Uncertainty [J]. The Accounting Review, 2008, 83(1): 665-703.

[15] Wu, Jia; Liu, Linxiao; Jones, Frederick, Firm value and earnings management after internal control weakness remediation [J], International Journal of Business Research, 2011, 11(5).

[16] Song Jingjin, Research on the motivation and economic consequences of internal control defect disclosure [M], Economic Science Press, 2015.

[17] Du Jianju, Hong Yanhua, Cao Jin, The influence of internal control defect disclosure and correction on enterprise value [J]. Journal of Suzhou College, 2017.2: 21-26.

[18] Gao Shengxing, Study on the impact of internal control defects on audit cost [J], Commercial Accounting, 2013, 8:71-73.

[19] Liu Yanfang, Empirical research on the influence of corporate governance characteristics on internal control defect repair [D], Shandong University of Finance And Economics, Mmaster, 2016.

[20] Zhu Caijie, Research on the influence of board governance on internal control defect repair -based on media supervision and regulation of legal regulation [D], Shandong University, Doctor, 2016. 